\title{
The Relation between Helicobacter Pylori Infection and Severity of Bronchial Asthma in Children
}

\author{
MARWA G.A. KHATER, M.Sc.*; NABIL M. EL-ESAWY, M.D.*; AHMED M. ABDEL-RAZIK, M.D.* and \\ NAHLA A. NOSAIR, M.D.** \\ The Departments of Pediatrics* and Clinical Pathology**, Faculty of Medicine, Tanta University, Tanta, Egypt
}

\begin{abstract}
Background: Asthma is a chronic lung disease characterized by wheezy chest, resulting from allergic inflammation and hyperresponsivness of the bronchi to various stimuli. Microbial exposures have been suggested to confer protection from allergic disorders and reduced exposures to gastrointestinal microbes have been proposed as an explanation for the increase in asthma prevalence and severity. Since the general prevalence of Helicobacter pylori has been decreasing, we hypothesized that H.pylori status may be inversely related to the severity of asthma.
\end{abstract}

Aim of Study: This study was coducted to evaluate the relation between Helicobacter pylori infection and bronchial asthma in children.

Patients and Methods: The study was carried out on sixty children with asthma who attended to the outpatient clinic of Chest and Allergic Diseases, Pediatric Department, Tanta University Hospital. Also, it included thirty apparently healthy children with matched age and sex who served as a control group. All studied children were subjected to full history taking, complete physical examination, pulmonary function test and detection of H.pylori antigen in stool by ELISA. Data was analyzed by using SPSS.

Results: There is significant association between severity of asthma and result of H.pylori so with increase severity of asthma there is decrease in percentage of positive H.pylori results. As regard pulmonary function tests (FEV 1 and PEFR), there was statistically significant difference between positive H.pylori asthmatic and negative H.pylori asthmatic children. There was no statistically significant difference between patient's sex or age and results of H.pylori infection test.

Conclusion: There is a significant inverse association between severity of asthma and result of H.pylori infection (by H.pylori Ag in stool). This association is not affected by ages and sex of patients.

Key Words: Bronchial asthma - H.pylori-H.pylori antigen in stool by ELISA.

Correspondence to: Dr. Marwa G.A. Khater

The Department of Pediatrics, Faculty of Medicine,

Tanta University

\section{Introduction}

ASTHMA is a common chronic inflammatory disease of the airways that is characterized by variable airway obstruction, hypersecretion of mucus, airway inflammation, and hyper-responsiveness of the airways [1].

There is wide geographical variation in the prevalence of asthma and allergic conditions worldwide, with substantial differences seen between low- and high-income countries, and between urban and rural communites [2].

In susceptible individuals, airway inflammation may cause recurrent or persistent bronchospasm, which causes symptoms that include wheezing, breathlessness, chest tightness, and cough, particularly at night [3].

H. pylori is a bacterium which colonizes the gastric mucosa of approximately half the world's population and is the main cause of peptic ulcer disease in children [4] .

The infection is usually established during early childhood, persists life long, and remains asymptomatic in over $85 \%$ of cases [5].

The majority of those colonized with H. pylori are actually asymptomatic, Even if $\mathrm{H}$. pylori does not cause disease, it does lead to a specific immune response in all humans [6]

H. pylori primarily activates a Th1 response and decreases the $\mathrm{Th} 2$ response, which is responsible for asthma so it decreases bronchial inflammation [7].

An hygiene hypothesis, states that the exposure to infectious agents and living in an unhygienic environment might "educate" the immune system 
and thus protect against the development of allergic diseases and asthma [8].

There is found significant inverse associations of H. pylori positivity with early onset of asthma and allergic rhinitis in children [9].

Aim:

This study was conducted to evaluate the relation between Helicobacter pylori infection and bronchial asthma in children.

\section{Patients and Methods}

This case control study was conducted on 60 asthma cases and 30 non asthma control cases who attended to the outpatient clinic of Chest and Allergic Diseases, Pediatric Department, Tanta University Hospital from December 2015 to December 2016.

Asthmatic patients (aged from 6-14 years) were categorized according to asthma severity into mild intermittent, mild persistent, moderate persistent and sever persistent based on revised GINA guidelines.

Exclusion criteria: Children who received antimicrobial, proton pump inhibitor, bismuth within 2 weeks before specimen and children who had gastero-intestinal bleeding.

Both patients and control groups were subjected to the following: Full history taking, clinical examination, Pulmonary function tests (FEV 1 and PEFR) by spirometry. At least three technically accepted maneuvers were performed and the best value was recorded [3], Helicobacter pylori Antigen in stool by ELISA (if +ve or -ve result) [10]. ELISA measurement of H.pylori Antigen ( $\mathrm{Hp} \mathrm{S} \mathrm{Ag)} \mathrm{in}$ human stools was performed and the results were interpreted using H.Pylori Antigen KT 824 manufacturer's instructions (Epitope Diagnostics, Inc). This ELISA kit is for in-vitro diagnostic use.

Statistical presentation and analysis of the present study was conducted using the mean, standard deviation, student $t$-test, Chi-square by SPSS V20 with $p<0.05$ means significance.

\section{Results}

This study was conducted on 60 cases with clinically definite asthma and 30 non asthma control cases, both patients and control were cross matched for age and sex.

Table (1) presents the demographics and laboratory data of the case control study population as regard age, sex, residence, family history of allergic diseases and eosinophil \%. It show no significant difference between the asthmatic children and controls as regard demographics data as age, sex and residence $(p$-value $>0.05)$ but show significant increase in family history of allergic diseases in asthmatic children as compared to controls ( $p$ value $>0.05$ ) and show that there is significant increase of blood eosinophil $\%$ in asthmatic children as compared to controls ( $p$-value $>0.05$ ) as shown in Table (1).

Table (1): Demographic and laboratory data of the studied groups.

\begin{tabular}{llll}
\hline & $\begin{array}{c}\text { Asthmatic } \\
\text { children } \\
(\mathrm{n})=60\end{array}$ & $\begin{array}{c}\text { Controls } \\
(\mathrm{n})=30\end{array}$ & $p$-value \\
\hline Age (Years) & $8.545 \pm$ & $7.950 \pm$ & 0.257 \\
Sex: & 2.424 & 2.131 & \\
$\quad$ Male & $55.00 \%$ & $56.67 \%$ & 0.881 \\
Female & $45.00 \%$ & $43.33 \%$ & \\
Residence: & & & \\
Urban & & & \\
Rural & $41.67 \%$ & $63.33 \%$ & 0.053 \\
Family history & $58.33 \%$ & $36.67 \%$ & \\
of allergic diseases: & & & \\
$\quad$ Negative & & & \\
$\quad$ Positive & 36.67 & 76.67 & $<0.001 *$ \\
Eosinophil \% & 63.33 & 23.33 & \\
& $2.353 \pm$ & $1.503 \pm$ & $<0.001 *$ \\
\hline & 1.223 & 0.600 & \\
\hline
\end{tabular}

Data are represented as mean \pm SD.

There is significant increase of blood eosinophil\% in asthmatic children as compared to controls ( $p$-value $>0.05$ ) as shown in Fig. (1)

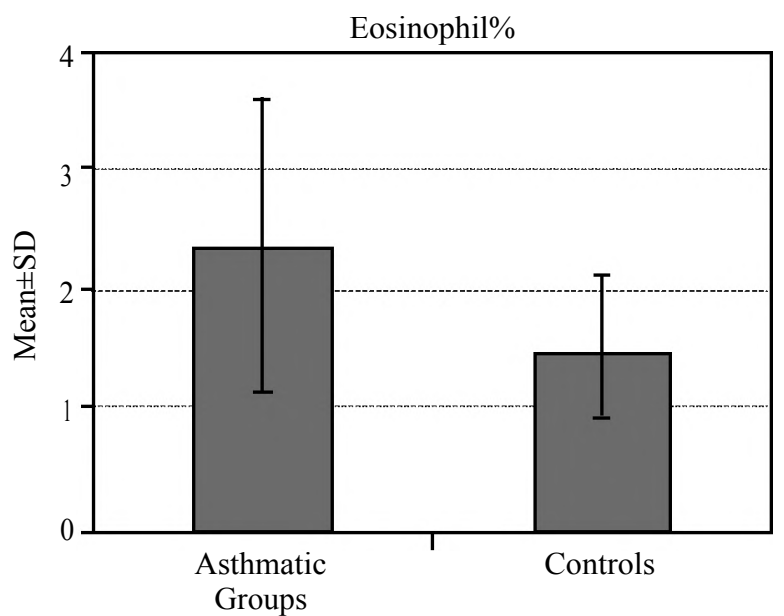

Fig. (1): Comparison between asthmatic children and controls as regard blood eosinophil\%.

Positive H.pylori was found in 26/60 (43.33\%) of asthmatic cases compared to $23 / 30(76.67 \%)$ of control with statistically significant difference $(p=$ 0.003 ) as shown in Table (2). 
Table (2): Distribution of H.Pylori among asthmatic children and controls.

\begin{tabular}{|c|c|c|c|c|c|c|c|c|}
\hline \multirow{3}{*}{$\begin{array}{l}\text { H.Pylori } \\
\text { Ag } \\
\text { In stool }\end{array}$} & \multicolumn{6}{|c|}{ Groups } & \multirow{2}{*}{\multicolumn{2}{|c|}{ Chi-Square }} \\
\hline & \multicolumn{2}{|c|}{$\begin{array}{l}\text { Asthmatic } \\
\text { children } \\
\text { (n) }=60\end{array}$} & \multicolumn{2}{|c|}{$\begin{array}{l}\text { Controls } \\
(n)=30\end{array}$} & \multicolumn{2}{|c|}{$\begin{array}{c}\text { Total } \\
(\mathrm{n})=90\end{array}$} & & \\
\hline & $\mathrm{N}$ & $\%$ & $\mathrm{~N}$ & $\%$ & $\mathrm{~N}$ & $\%$ & $\mathrm{X}^{2}$ & $p$-value \\
\hline Negative & 34 & 56.67 & 7 & 23.33 & 41 & 45.56 & 8.960 & $0.003 *$ \\
\hline Positive & 26 & 43.33 & 23 & 76.67 & 49 & 54.44 & & \\
\hline Total & 60 & 100.00 & 30 & 100.00 & 90 & 100.00 & & \\
\hline
\end{tabular}

There was no significant difference between asthmatic children regarding the sex and H.pylori $(p$-value $>0.05)$ as shown Table (3).

Table (3): Comparison between positive and negative H.pylori asthmatic children regarding sex.

\begin{tabular}{|c|c|c|c|c|c|c|c|c|}
\hline & \multicolumn{6}{|c|}{ H.Pylori Ag } & \multirow{2}{*}{\multicolumn{2}{|c|}{ Chi-Square }} \\
\hline & \multicolumn{4}{|c|}{ Negative Positive } & \multicolumn{2}{|c|}{ Total } & & \\
\hline & $\mathrm{N}$ & $\%$ & $\mathrm{~N}$ & $\%$ & $\mathrm{~N}$ & $\%$ & $X^{2}$ & $p$-value \\
\hline \multicolumn{9}{|l|}{ Sex: } \\
\hline Male & 18 & 52.94 & 15 & 57.69 & 33 & 55.00 & 0.134 & 0.714 \\
\hline Female & 16 & 47.06 & 11 & 42.31 & 27 & 45.00 & & \\
\hline
\end{tabular}

There is significant association between pulmonary function and result of H.pylori Ag in stool, so with positive H.pylori results increase in percentage of FEV $1 \&$ PEFR (\%predicted) as shown in Table (4) and Fig. (2).

Table (4): Comparison between positive and negative H.pylori asthmatic children regarding FEV 1 \& PEFR (\%predicted).

\begin{tabular}{lllll}
\hline & \multicolumn{2}{c}{ H.Pylori Ag } & \multicolumn{2}{c}{$t$-Test } \\
\cline { 2 - 5 } & Negative & Positive & $t$ & $p$-value \\
\hline FEV $V_{1}$ (\%predicted): & & & & \\
$\quad$ Range & $53-91$ & $52-98$ & -3.186 & $0.002^{*}$ \\
Mean \pm SD & $73.765 \pm$ & $83.077 \pm$ & & \\
& 12.010 & 10.083 & & \\
& & & & \\
PEFR (\%predicted): & & & & \\
Range & $34-79$ & $38-77$ & -2.776 & $0.007^{*}$ \\
Mean \pm SD & $58.912 \pm$ & $67.346 \pm$ & & \\
& 12.967 & 9.674 & & \\
\hline
\end{tabular}

There is significant negative association between severity of asthma and result of H.pylori Ag in stool, so with increase severity of asthma there is decrease in percentage of positive H.pylori results ( $p$-value $=0.026)$ as shown in Fig. (2).

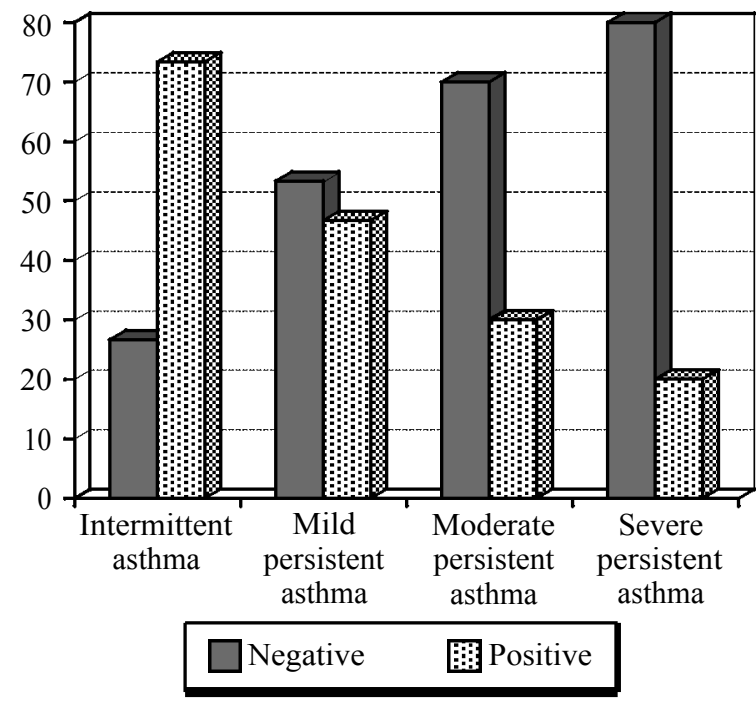

Fig. (2): H.pylori (Ag in stool) in relation to severity of asthma (mild intermittent \& mild, moderate, severe persistent respectively).

\section{Discussion}

Reduced exposure to orofecal organisms has been suggested as an explanation for the increasing prevalence of atopy and asthma, but studies of multiple organisms have had conflicting results [10]. H.pylori are among organisms that infect humans as they colonize the gastric mucosa in early life and then produce a chronic persisting infection and an inflammatory response that persists indefinitely unless eradicated [11,12].

This study shows the relationship between H.pylori infection and severity of asthma. In this study, Distribution of H.Pylori by stool Ag test was in asthmatic children $43.33 \%$ and in controls $76.67 \%$. So, H.pylori was significantly lower in asthmatic children than controls ( $p$-value $>0.003$ ).

This result is consistent with Arram et al., study [10], Out of 41 asthmatic cases with positive $\mathrm{H}$. pylori, there were 22 patients who had mild asthma, 14 had moderate asthma, and 5 only had severe asthma with statistically significant difference between them. There was statistically significant difference between positive H.pylori asthmatic and negative $\mathrm{H}$.pylori asthmatic as regard pulmonary function tests (FEV1 and FVC) $(p=0.03,0.05)$ respectively.

Finding of inverse associations between $\mathrm{H}$. pylori status and childhood asthma is also consistent with evidence from Kozyrskyj et al., [13] that antibiotic use for treatment of non-respiratory tract infections during the first year of life subsequently leads to an increased risk of childhood asthma. 
Our result is consistent with Chen and Blaser study [9], in their cross-sectional analyses conducted using data from 7412 children which showed that H.pylori seropositivity was inversely associated with asthma in pediatric age, and the inverse association with onset of asthma before 5 years of age was stronger.

Raj et al., study [14] proposed that H.pylori infection possibly will be an only indicator of poor hygiene and the poor hygiene through the hygiene theory of more exposure to the infectious agents, results in a low prevalence of asthma.

Matricardi et al., study [12] found that asthma and rhinitis were inversely related to gradient of exposure to the microbes as $\mathrm{H}$. pylori, Toxoplasma gonadii and hepatitis A.They suggested that the route of transmission of a childhood acquired pathogen (e.g. oral vs respiratory) was more important than the specific pathogen to drive the immune system toward a T-helper (Th) 1 response which acts protectively against atopy. As such, $\mathrm{H}$. pylori may also be a marker for the presence of other antigens that are often concomitantly present, owing to the inverse association of the bacterium and household hygiene.

Our observations were consistent with the results of a meta-analysis done by Wang et al., study [15] which showed that there was a weak evidence for an inverse association between asthma and $\mathrm{H}$. pylori infection.

Zevit et al., [16] and Reibman [17] studies also revealed that there is an inverse association between $\mathrm{H}$. pylori seropositivity and pediatric asthma and that $\mathrm{H}$. pylori is an independent factor that protects against asthma. All these studies suggest that there are several mechanisms by which H.pylori affect asthma.

There is a wealth of published data demonstrating that $\mathrm{H}$. pylori infection induces high-level Treg, Th1, and Th17 responses in both humans and mouse models. Interferon-gamma (IFN $\gamma$ )-secreting Th1 cells are associated with increased gastric inflammation and disease, whereas Treg inhibiting inflammation are associated with reduced incidence of disease and probably contribute to the life-long persistence of H.pylori infections. They are known to be important for suppressing autoimmunity, allergy, and inflammation [18]

Increased levels of Treg cells and/or Th1 cells in the circulation influence immune responses at extra-gastric sites in the body and may play a role in preventing an elevated Ig E response [19].
This may be the result of an inhibition of allergic Th- 2 inflammation exerted by Th- 1 responses; the latter are elicited by infectious agents and are able to induce the production of IFN- $y$, IL-12, IL-18 and IL-23 [6]

Bronchial asthma and allergic diseases are characterized by Th2 inflammation which is strongly inhibited by IL-12 and IFN- $y$. It is demonstrated that in allergic asthmatic patients, the typical Th2 responses can be redirected toward Th1 by the neutrophil-activating protein of H.pylori (HP-NAP) [20].

These results provide the possibility that HPNAP might be a part of the molecular mechanism underlying the negative association between $\mathrm{H}$. pylori infection and allergy. Finally, the potential use of HP-NAP as a new tool for the prevention and treatment of asthma and allergy will also be considered [21].

An alternative mechanism for the negative association is that $\mathrm{H}$. pylori acts as a surrogate marker for antibiotic use. Children with asthma have been shown to receive more courses of antibiotics than non-asthmatic children. As such, children with asthma may undergo low-level eradication of H.pylori during these excess episodes of antibiotic treatments when compared to nonasthmatics [22].

Our result is not consistent with Karimi et al., study [23] who reported that no significant difference between H.pylori infection and childhood asthma. But, they found an association between increased age and prolonged duration of disease in asthmatic children with more incidences of H.pylori infection.

Also, Our study results were not consistent with Fullerton et al., study [24] as they found that there is no significant association between H.pylori infection and asthma protection. Their study was conducted on 2437 adults aged 18-70 year, failed to find any association between positive $\mathrm{H}$. pylori infection and either COPD, asthma, allergic diseases, atopic diseases or abnormal PFT.

Furthermore, results from a community-based study of young adults provided no evidence that seropositive H.pylori patients had a lower level of $\operatorname{IgE}$ sensitization [25]

In a study done by National Heart lung and Blood Institute (NHLBI) on asthmatic patients 18 years of age and older, It was hypothesized that vaculoating cytotoxin $A$ and other toxins produced by $\mathrm{H}$. pylori may have a role in the pathogenesis 
of lung disease and in the subclinical decline in lung functions seen with aging [26].

The discrepancy between the results in different studies may be due to the difference in the number of sampled patients and use IgE level and spirometry to assess asthma severity.

\section{Conclusion:}

There is significant inverse association between severity of asthma and results of H.pylori stool Ag. This association not affected by age and sex of patients.

\section{Acknowledgments:}

This research was carried out without funding.

\section{Conflicts of interest:}

No conflicts of interest declared.

\section{Authors' Contributions:}

All authors had equal role in design, work, statistical analysis and manuscript writing. All authors have approved the final article work.

\section{References}

1- BHAKTA N.R. and WOODRUFF P.G.: Human asthma phenotypes: From the clinic, to cytokines, and back again. Immunol. Rev., 24 (2): 220-32, 2011.

2- EDER W., EGE M.J. and VON MUTIUS E.: The asthma epidemic. N. Eng.1 J. Med., 355: 2226-35, 2006.

3- Global Strategy for Asthma Management and Prevention: Global initiative for asthma (GINA). Available at http://ginasthma.org ., 2015.

4- ROBINSON K. and ATHERTON J.C.: Helicobacter pylori. Sequelae and long term consequences of infectious diseases. ASM Press, 107-33, 2009.

5- Atherton J.C. and Blaser M.J.: Coadaptation of Helicobacter pylori and humans: Ancient history, modern implications. J. Clin. Invest, 119: 2475-87, 2009.

6- OERTLI M., SUNDQUIST M., HITZLER I., et al.: DCderived IL-18 drives Treg differentiation, murine Helicobacter pylori-specific immune tolerance, and asthma protection. J. Clin. Invest, 122: 1082-96, 2012.

7- D'ELIOS M.M., CODOLO G., AMEDEI A., et al.: Helicobacter pylori, asthma and allergy. FEMS Immunol Med Microbiol, 56: 1-8, 2009.

8- MCLOUGHLIN R.M. and MILLS K.H.: Influence of gastrointestinal commensal bacteria on the immune responses that mediate allergy and asthma. J. Allergy Clin. Immunol., 127: 1097-107, 2011.

9- CHEN Y. and BLASER M.J.: Helicobacter pylori colonization is inversely associated with childhood asthma. J. Infect Dis., 198: 553-60, 2008.

10- KORKMAZ H., KESLI R., KARABAGLI P., et al.: Comparison of the diagnostic accuracy of five different stool antigen tests for the diagnosis of Helicobacter pylori infection. Helicobacter, 18: 384-91, 2013.
11- EVERHART J.E., KRUSZON-MORAN D., PEREZPEREZ G.I., et al.: Seroprevalence and ethnic differences in Helicobacter pylori infection among adults in the United States. The Journal of Infectious Diseases, 181 (4): 135963, 2000.

12- MATRICARDI P.M., ROSMINI F., PANETTA V., et al.: Hay fever and asthma in relation to markers of infection in the United States. Journal of Allergy and Clinical Immunology, 110 (3): 381-7, 2002.

13-ARRAM E.O., SHAHIN D.A. and SHERIF M.M.: Asthma is inversely associated with Helicobacter pylori status. Egyptian Journal of Chest Diseases and Tuberculosis, 61 (3): 41-5, 2012.

14- RAJ S.M., CHOOK E., NOORIZAN A.M., et al.: Evidence against helicobacter pylori being related to childhood asthma. J. Infect Dis, 199: 914-5.

15- WANG Q., YU C. and SUN Y.: The association between asthma and Helicobacter pylori: A meta-analysis. Helicobacter, 18: 41-53, 2013.

16-ZEVIT N., BALICER R.D., COHEN H.A., et al.: Inverse association between H.pylori and asthma in high prevalence population. Helicobacter, 17: 3035.

17- REIBMAN J., MARMOR M., FILNER J., et al.: Asthma Is Inversely Associated with Helicobacter pylori Status in an Urban Population. PloS. One., 3 (12): e4060, 2008.

18- ROBINSON K., KENEFECK R., PIDGEON E.L., et al.: Helicobacter pylori-induced peptic ulcer disease is associated with inadequate regulatory $\mathrm{T}$ cell responses. Gut, 57 (10): 1375-85, 2008.

19-RAD R., BRENNER L., BAUER S., et al.: CD25+/Foxp3+ $T$ cells regulate gastric inflammation and Helicobacter pylori colonization in vivo. Gastroenterology, 131 (2): 525-37, 2006.

20- AMEDEI A., CAPPON A., CODOLO G., et al.: The neutrophil-activating protein of Helicobacter pylori promotes Th1 immune responses. J. Clin. Invest, 116: 1092 101, 2006.

21- Codolo G., Mazzi P., Amedei A., et al.: The neutrophilactivating protein of Helicobacter pylori down-modulates Th2 inflammation in ovalbumin-induced allergic asthma. Cell Microbiol., 10: 2355-63, 2008.

22- KOZYRSKYJ, ANITA L., PIERRE ERNST and ALLAN B. BECKER: Increased risk of childhood asthma from antibiotic use in early life. CHEST Journal, 131 (6): 17539, 2007.

23- KARIMI A., FAKHIMI-DERAKHSHAN K., IMANZADEH F., et al.: Helicobacter pylori infection and pediatric asthma. Age (years), 8 (2.04): 8-43, 2012.

24- FULLERTON D, BRITTON JR, LEWIS SA, et al.: Helicobacter pylori and pulmonary function, asthma, atopy and allergic disease: A population-based cross-sectional study in adults. Int. J. Epidemiol., 38: 419-26, 2009.

25- JARVIS D., LUCZYNSKA C., CHIN S., et al.: The Association of hepatitis A and Helicobacter Pylori with sensitization to common allergens, asthma and hay fever in a population of young British adults. Allergy, 59: 10637, 2004

26- NHLBI: Expert Panel Report 3: Guidelines for the Diagnosis and Management of Asthma, 1-250, 2007. 


\section{العلاقة بين عدوى الجرثومة الحلزونية ودرجة خطورة الريو الشعبى فئ الأطفال}

الريو الشعبى هو التهاب مزمن فى الشعب الهوائية ويتميز بانسداد مجرى الهواء فرط المخاط، وفرط الا ستجابة فى الشعب الهوائية، ولا

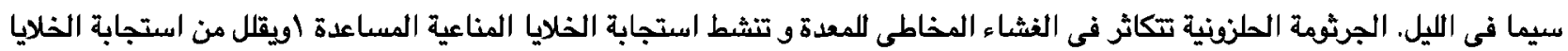

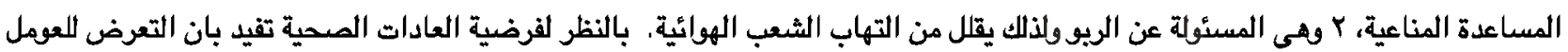
المعدية والعيش فى بيئة غير صحية قد يسبب (تثقيف) مناعى وحماية ضد تطوير امراض السئل الصساسية والريو.

$$
\text { الهدف من الدراسة: هو تقييم العلا قة بين الجرثومة الطلزونية والربو الشعبى فىالاطفال. }
$$

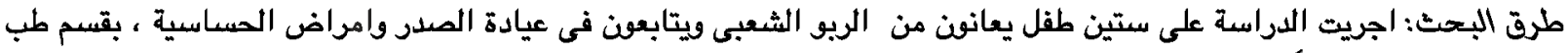

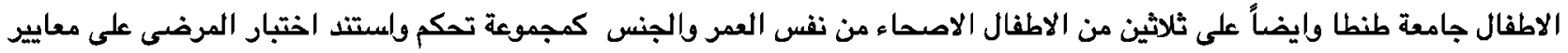

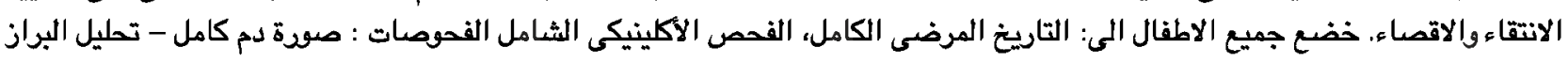

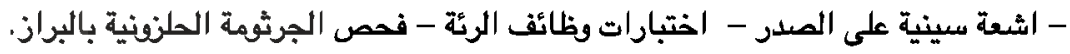

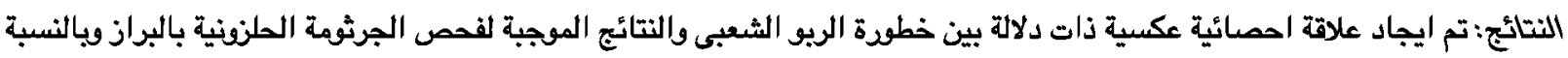

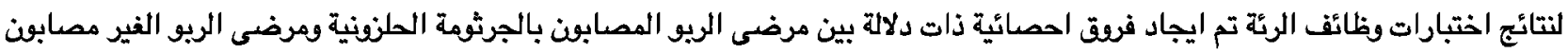

الاستتاج: هناك علاقة عكسية بين شدة الريو الشعبى والنتائج الموجبة لفحص الجرثومة الحلزونية بالبراز.

التوصيات: بونحن نوصي النظر بدقة حول ما إذا كان عدم القضاء على البكتيريا الطلزونية البوابية فى الأطفال قد تلعب دودا فى تقليل

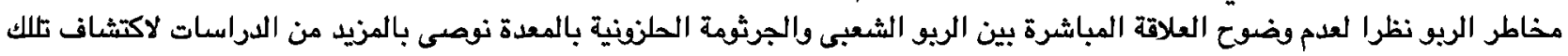

